TECHNICAL TRANSACTIONS 6/2017

CZASOPISMO TECHNICZNE 6/2017

CIVIL ENGINEERING

DOI: $10.4467 / 2353737$ XCT.17.091.6567

\title{
Lucyna Korona
}

Technical Department, Kujawy and Pomorze, University in Bydgoszcz

Janusz Tadeusz Barski (barski@uwm.edu.pl)

Institute of Building Engineering, Faculty of Geodesy, Geospatial and Civil Engineering,

University of Warmia and Mazury in Olsztyn

\section{ANALYSIS OF TYPE OF CONSTRUCTION PROJECTS IN TENDER FORMULA "DESIGN AND BUILD"}

\section{ANALIZA STRUKTURY RODZAJOWEJ PRZEDSIĘWZIĘĆ BUDOWLANYCH W FORMULE PRZETARGOWEJ "ZAPROJEKTUJ I WYBUDUJ"}

\begin{abstract}
The construction undertakings are being realized within two basic formulas:

- Design and separately execution of works - ("P") $+($ "B"),

- Design and built $-(" \mathrm{P}+\mathrm{B}$ ”) otherwise called as "design and execution of works" („Zi W").

The project realization procedure depends on the kind of undertaking and resources of the contracting authority. The choice of formula has an influence on the undertaking preparation as well as on the choice of executor and project realization. The article shows the results of research and defines the percent participation of the individual type of construction undertakings in "design and execution of work" formula that were realized in Poland in the years 2010-2016. "Design and execution of work" formula is used rarely in public procurements. The above-mentioned is confirmed by nation-wide statistic data and statistic data for the Kujawsko-Pomorskie and Warmińsko-Mazurskie provinces.
\end{abstract}

Keywords: public procurements, "design and build" formula, tendering mode, contracting authority, statistic data

\section{Streszczenie}

Przedsięwzięcia budowlane realizowane są w ramach zamówień publicznych w dwóch podstawowych formulach:

- „Projekt” i odrębnie „Budowa” - („P”) + („B”),

- „Projekt wraz z Budową" - (,P + B”) inaczej zwaną „zaprojektuj i wybuduj” („Zi i W”).

Procedura realizacji projektu następuje w zależności od rodzaju przedsięwzięcia a także posiadanych zasobów przez Zamawiającego. Wybór formuly ma wplyw na przygotowanie przedsięwzięcia i tym samym wyłonienie Wykonawcy oraz realizację, czyli administrowanie projektem. W artykule przedstawiono wyniki badań dokumentacyjnych, określając procentowy udział poszczególnych rodzajów przedsięwzięć budowlanych zrealizowanych w latach 2010-2016 w formule „zaprojektuj i wybuduj” w Polsce. Formula „zaprojektuj i wybuduj” jest rzadziej stosowana w zamówieniach publicznych, na co wskazują dane statystyczne ogólnokrajowe oraz przykladowo dla dwóch województw: kujawsko-pomorskiego i warmińsko-mazurskiego.

Słowa kluczowe: zamówienia publiczne, formuła „zaprojektuj i wybuduj”, tryby przetargowe, zamawiający, dane statystyczne 


\section{Introduction}

Works contracts in the sector of the socialized enterprises are subject to the Public Procurement Law and its relevant regulations. The law regulating auctions for works and construction services was first introduced in 1918. The regime change of 1945 and dynamically developing market economy, as well as the Polish accession to the European Union, have forced numerous and significant changes in legislation, adapting them to the current requirements.

The current system of public procurement has now been in force for twenty-three years. The first legal regulation on the award of the contract came into force in 1994. A big change in the law occurred in 2004, when Poland became a member of the European Union and had "Public Procurement Law" adapt to European standards. The obligation to use the Public Procurement Act and the announcement of auction procedures, to April 15, 2014, applied to contracts with a minimum threshold of 14000 EURO of estimated value. From 16 pril 2014, the minimum threshold of the estimated value of the contract was increased to 30000 EURO. A purchaser conducting the public procurement procedure must be guided by the principle of fair competition, objectivity and transparency of procedures. The Act on Public Procurement Law introduced a variety of types and forms of procurement. Hence, the problem for the investor/purchaser, especially the public, is to choose the right kind of tender, and its formula. For several years, it has been practiced in public procurement, in addition to the so-called "classic" formula using formula "design and build".

The focus of the authors of this study is a demand of purchasers to use the formula of "design and build", kind and nature of the ongoing construction projects in this formula.

In order to determine the statistical data, announcements concerning tenders granted in the period from 2010-2016 were analyzed, published in the Bulletin of Public Procurement by the Public Procurement Office on its website, as well as the report of the President on/in the office, conducted interviews with several customers and used the available literature thematic.

\section{The essence and the basic assumptions adopted in public procurement carried out in the formula of "design and build"}

One of the many possible tender formulas used in different countries is a system of "design and build". It was used for the first time in the US, where in recent years, the popularity of "design and build" significantly increased. This method of implementation of the investment has become one of the most significant global trends in today's construction industry.

The procedure for "design and build" assumes the implementation of the contract by the contractor, including the preparation of comprehensive design documentation. As a result of the tender procedure is showdown to determine only one subject that prepares construction design, technical projects, obtains permission or notification to build, and then performs works according to the documentation prepared. From the point of view of the customer, it is a convenient system of investment. 
Model approach to the selection of contractor for the investment in Poland is different than in Western countries, as the general contractor contract is the one who has the larger share of the contract value. On the Polish construction sites general contractor, in the "design and build" formula, is usually a company that implements construction works and subcontracts the execution of the project and obtaining the necessary administrative decisions to the design firm. In Western countries, the leader is generally the design or architectural-managerial company, which prepares a draft, subcontracts and exercises supervision over the implementation of the project (Fig. 1).

The basic premise of the "design and build" is the idea that the contracts concluded in this system should allow contractors to propose their own innovative solutions, for the benefit of both the Contractor and the Employer, and be implemented faster and cheaper. They are also addressed at those applicants who do not have sufficient knowledge or experience in the implementation of the project. With projects in the formula " $\mathrm{Z}$ and $\mathrm{W}$ ", there is no requirement to provide full documentation to the application for funding from the EU.

Obtaining comprehensive documentation, required permits or applications lies with the Contractor who will be selected by means of the tender procedure. The purchaser describes the subject of the contract using functional - utility object program description (PFU), including a description of the construction task, which is the object of the contract (Art. 31, paragraph. 2 and 3 of the Public Procurement Law). In the functional - utility program should be given destiny of completed construction works and the requirements imposed on them (technical, economic, architectural, material and functional). In the "design and build", often identified with the yellow FIDIC, the investor should no longer interfere in the project. The project manager should have the freedom to design, limited only to the records included in the PFU.
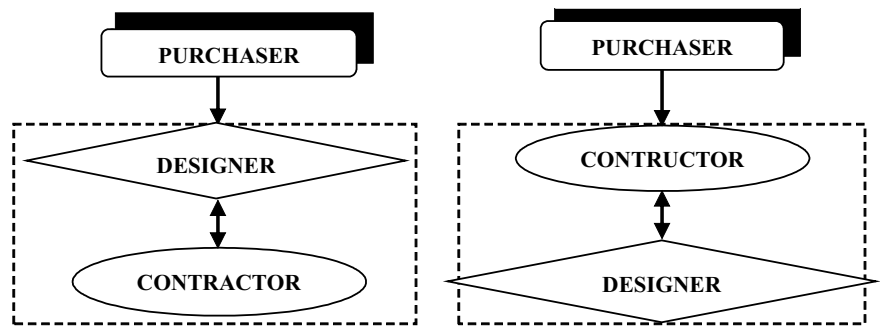

Fig. 1. Model selection of a public contract in the formula of "design and build": a) business model of Western countries, eg. German, Austrian, American, b) the prevailing model of operations in Poland, resulting from the Public Procurement Law

\section{Public procurement in the years 2010-2016}

The number of contracts awarded in the period 2010-2016 are presented in Table 1. It can be stated that in the years 2010-2016, there was:

- A decrease of $41.59 \%$ in the total number of public contracts awarded,

- A decrease of $47.58 \%$ in the number of contracts awarded by public works contracts,

- An increase of $329.76 \%$ in the number of all public contracts awarded in the formula $\mathrm{Z}$ and $\mathrm{W}$, 
- An increase of $368.57 \%$ in the number of contracts awarded by public works the formula " $\mathrm{Z}$ and $\mathrm{W}$ ".

Despite the decline in the number of public contracts awarded, the formula of "design and build" is growing in popularity.

This is due to the fact that in the formula $\mathrm{Z}$ and $\mathrm{W}$, the Purchaser prepares a description of the object of the contract with the functional program. It eliminates the necessity to describe the object of contract by the drafting of construction and technical execution and acceptance of construction works, which is more time consuming compared to the functional program.

The percentage participation of the "design and build" formula is shown in Fig. 2. A smaller share of formula " $Z$ and W" in all contracts awarded in 2010-2016 shows that these orders include construction, services and supplies. The formula " $\mathrm{Z}$ and $\mathrm{W}$ " in the reporting period was mainly used in the award of a contract works, which required the development of a building design project and construction.

Table 1. The number of contracts awarded in the period 2010-2016

\begin{tabular}{|c|c|c|c|c|c|c|c|}
\hline $\begin{array}{c}\text { Procurement } \\
\text { numbers }\end{array}$ & $\mathbf{2 0 1 0}$ & $\mathbf{2 0 1 1}$ & $\mathbf{2 0 1 2}$ & $\mathbf{2 0 1 3}$ & $\mathbf{2 0 1 4}$ & $\mathbf{2 0 1 5}$ & $\mathbf{2 0 1 6}$ \\
\hline $\begin{array}{c}\text { The total number of } \\
\text { granted } \\
\text { procurement }\end{array}$ & 186902 & 177886 & 179250 & 181061 & 152606 & 118042 & 77734 \\
\hline $\begin{array}{c}\text { Number of construction works } \\
\text { contracts in } \\
\text { procurement }\end{array}$ & 57364 & 49442 & 48957 & 47764 & 46536 & 37316 & 27295 \\
\hline $\begin{array}{c}\text { Number of contracts } \\
\text { procurement in } \\
\text { the formula „Z and W” }\end{array}$ & 84 & 158 & 222 & 272 & 359 & 325 & 277 \\
\hline $\begin{array}{c}\text { Number of construction works } \\
\text { contracts in procurement } \\
\text { works in the formula } \\
\text { „Z and W” }\end{array}$ & 70 & 132 & 186 & 241 & 325 & 307 & 258 \\
\hline
\end{tabular}

Source: Own calculations based on Public Procurement Bulletin

The value of contracts awarded in the period 2010-2016 are presented in Table 2. After analyzing the number of contracts awarded and their values, we find:

- The average value of a contract awarded in total amounted to:

$\triangleright$ in 2010-0,894 mln zl,

$\triangleright$ in $2011-0,810 \mathrm{mln} \mathrm{zl}$,

$\triangleright$ in $2012-0,740 \mathrm{mln} \mathrm{zl}$,

$\triangleright$ in 2013-0,791 mln zl,

$\triangleright$ in $2014-0,906 \mathrm{mln} \mathrm{zl}$,

$\triangleright$ in $2015-0,985 \mathrm{mln} \mathrm{zl}$, 
- the average value of a contract awarded for construction works was:

$\triangleright$ in 2010-1,252 mln $\mathrm{zl}$,

$\triangleright$ in $2011-1,136 \mathrm{mln} \mathrm{zl}$,

$\triangleright$ in $2012-1,220 \mathrm{mln} \mathrm{zt}$,

$\triangleright$ in 2013-1,139 mln $\mathrm{zt}$,

$\triangleright$ in $2014-1,145 \mathrm{mln} \mathrm{zl}$,

$\triangleright$ in 2015-1,029 mln $\mathrm{zt}$.

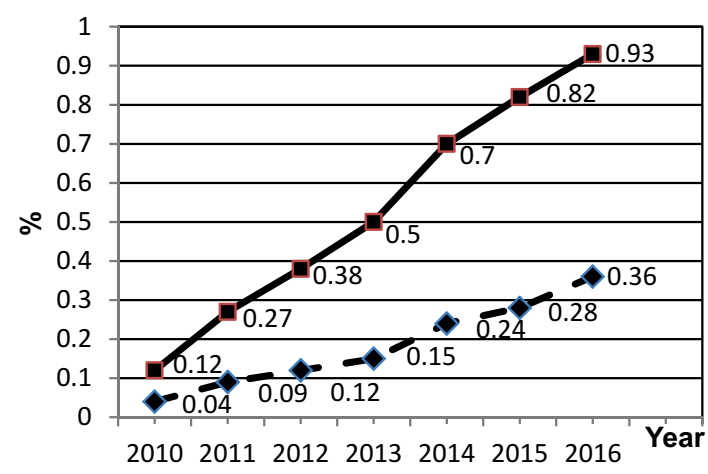

$\longrightarrow$ \% share of formula

"Zand W" in all contracts awarded

- $\%$ share of formula "Zand W" in awarded contracts for construction works

Fig. 2. Percentage participation of formula " $\mathrm{Z}$ and $\mathrm{W}$ " in the contracts awarded in the period $2010-2016$

The above collation clearly shows that the construction works had an average value of one contract awarded greater than the average value of a contract awarded in total

Table 2. The value of contracts awarded in the period 2010-2016

\begin{tabular}{|c|c|c|c|c|c|c|c|}
\hline $\begin{array}{l}\text { The value } \\
\text { Of contracts }\end{array}$ & $\mathbf{2 0 1 0}$ & $\mathbf{2 0 1 1}$ & $\mathbf{2 0 1 2}$ & $\mathbf{2 0 1 3}$ & $\mathbf{2 0 1 4}$ & $\mathbf{2 0 1 5}$ & $\mathbf{2 0 1 6 ^ { * }}$ \\
\hline total orders (mld zl) & 167.0 & 144.1 & 132.7 & 143.2 & 133.2 & 116.31 & - \\
\hline $\begin{array}{c}\text { Orders for construction } \\
\text { works (mld zl) }\end{array}$ & 71.81 & 56.19 & 59.71 & 54.41 & 53.28 & 38.38 & - \\
\hline
\end{tabular}

Source: Own calculations based on Reports Procurement Office.

* Purchaser is obliged to 1 March 2017 to submit a report.

In the analyzed period, orders were granted in different modes, as shown in Table 3. Considering the modes of public procurement is the most common procurement in general and open tender as well as the free-hand orders mode were used for construction. Award of contract in free-hand order mode usually referred to the additional and replacement works. Despite the limited tender being one of the basic procedures of public procurement in the years 2010-2016, it was used occasionally. This is possibly due to the longer term of proceedings. In the analyzed period, the procedure for awarding the concession for the service was not used because of the specifics of the contract award procedure. 
Table 3. Public procurement divided in mode of granting them in the years $2010-2016$

\begin{tabular}{|c|c|c|c|c|c|c|c|}
\hline $\begin{array}{l}\text { Number } \\
\text { of orders } \\
\text { according to mode }\end{array}$ & 2010 & 2011 & 2012 & 2013 & 2014 & 2015 & 2016 \\
\hline $\begin{array}{l}\text { The total number of } \\
\text { granted procurement } \\
\text { including: }\end{array}$ & 186902 & 177886 & 179250 & 181061 & 152606 & 118042 & 77734 \\
\hline - Unlimited tender & 142496 & 144849 & 149749 & 152169 & 129908 & 100804 & 68294 \\
\hline - Restricted tender, & 762 & 564 & 642 & 609 & 574 & 393 & 403 \\
\hline $\begin{array}{l}\text { Negotiations with the } \\
\text { announcement, }\end{array}$ & 195 & 144 & 81 & 67 & 59 & 25 & 23 \\
\hline $\begin{array}{l}\text { Negotiated procedure } \\
\text { without publication, }\end{array}$ & 498 & 247 & 146 & 134 & 98 & 59 & 39 \\
\hline - Competitive dialogue & 41 & 50 & 28 & 19 & 19 & 10 & 8 \\
\hline - Free-hand mode & 35872 & 26401 & 23817 & 23654 & 18970 & 14568 & 7708 \\
\hline - Question about price, & 6682 & 5368 & 4466 & 3988 & 2622 & 1848 & 1096 \\
\hline - Electronic bidding, & 356 & 263 & 231 & 421 & 356 & 335 & 163 \\
\hline - Service concession. & 0 & 0 & 0 & 0 & 0 & 0 & 0 \\
\hline $\begin{array}{l}\text { Number of construction } \\
\text { works contracts in } \\
\text { procurement including: }\end{array}$ & 57364 & 49442 & 48957 & 47764 & 46536 & 37316 & 27295 \\
\hline - Unlimited tender & 48244 & 41708 & 41872 & 40851 & 39993 & 31654 & 24513 \\
\hline - Limited tender & 470 & 263 & 273 & 307 & 249 & 202 & 221 \\
\hline $\begin{array}{l}\text { Negotiations with the } \\
\text { announcement, }\end{array}$ & 21 & 21 & 12 & 12 & 11 & 1 & 2 \\
\hline $\begin{array}{l}\text { Negotiated procedure } \\
\text { without publication, }\end{array}$ & 234 & 98 & 50 & 51 & 39 & 26 & 9 \\
\hline - Competitive dialogue & 6 & 5 & 3 & 6 & 7 & 4 & 4 \\
\hline - Source procurement, & 8269 & 7268 & 6643 & 6414 & 6081 & 5336 & 2473 \\
\hline - question about price, & 14 & 10 & 9 & 6 & 12 & 3 & 5 \\
\hline - Electronic bidding, & 106 & 69 & 95 & 117 & 114 & 90 & 68 \\
\hline - Service concession & 0 & 0 & 0 & 0 & 0 & 0 & 0 \\
\hline
\end{tabular}

Source: Own calculations based on Public Procurement Bulletin.

The percentage participation of modes in awarded public contracts in construction works in the formula of "design and build" is shown in Fig. 3. The growth in formula "design and build" in the contract award for construction works in 2016 was over 3-times compared to 2010. In 
2010-2016 in the award of public contracts in construction works in the formula " $\mathrm{Z}$ and W" share of open tendering was over $90.00 \%$ and had a downward trend. The decrease share of unlimited mode in 2016 amounted to 4.02 percentage points. There was an increase in 2016 of the share of electronic bidding mode by 92.55 percentage points compared to 2012 .

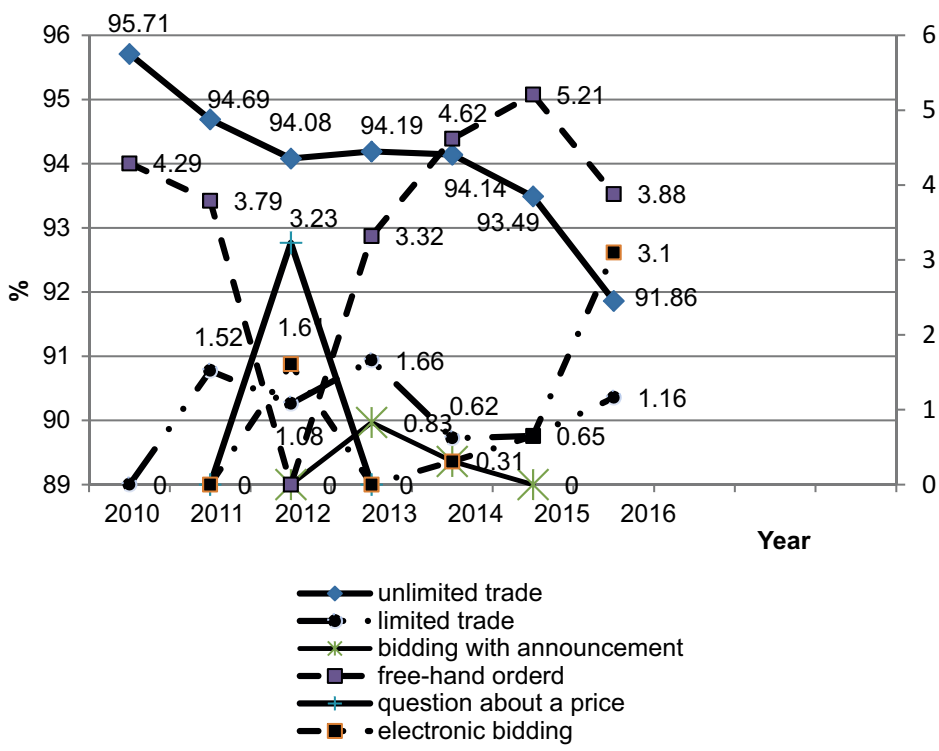

Fig. 3. Percentage participation of modes of procurement contracts in awarded public works for construction works in the formula of "design and build"

It is worth noticing that in the years 2010-2016 in the contracts awarded, public works for construction works have not been used in the contract mode: negotiations without announcement, competitive dialogue, service concession.

\section{Tenders in the years 2010-2016 in two selected provinces}

For comparative testing, two provinces with a similar economy were chosen. The number of contracts awarded in the Kujawsko-Pomorskie and Warmia and Mazury for the years 2010-2016 are presented in Table 4.

The data (Tab. 4) shows that in the analyzed period, more contracts and construction works contracts were awarded in the Kujawsko-Pomorskie than in the Warmia-Mazury. Despite fewer contracts awarded in the Warmia-Mazury, formula "design and build" was used more often. $23.26 \%$ more public works contracts were awarded in this formula than in the Kujawsko-Pomorskie This was caused by a greater number of factors of procurement: renovation, modernization of facilities, road infrastructure, municipal infrastructure, what is shown in Table 5. 
Table 4. Public procurement in the years 2010 - 2016 in Kujawsko-Pomorskie and Warmia-Mazury*

\begin{tabular}{|c|c|c|c|c|c|c|c|}
\hline $\begin{array}{ll}\begin{array}{l}\text { Number of } \\
\text { orders }\end{array} & \text { Year }\end{array}$ & 2010 & 2011 & 2012 & 2013 & 2014 & 2015 & 2016 \\
\hline $\begin{array}{l}\text { Contracts awarded } \\
\text { in the province. Kuj-pom. }\end{array}$ & 8503 & 8633 & 8239 & 8238 & 7214 & 5721 & 3737 \\
\hline $\begin{array}{c}\text { Construction works } \\
\text { contracts awarded } \\
\text { in the province. Kuj-pom. }\end{array}$ & 2559 & 2369 & 2246 & 2348 & 2221 & 1876 & 1361 \\
\hline $\begin{array}{l}\text { Contracts awarded in the } \\
\text { formula "Z and } \mathrm{W} \text {, in the } \\
\text { province. Kuj-pom. }\end{array}$ & 3 & 4 & 7 & 7 & 13 & 11 & 6 \\
\hline $\begin{array}{l}\text { Construction works } \\
\text { contracts awarded } \\
\text { in the formula „Z and W” } \\
\text { in the province. Kuj-pom. }\end{array}$ & 3 & 4 & 7 & 6 & 10 & 9 & 6 \\
\hline $\begin{array}{l}\text { Contracts awarded } \\
\text { in the province. war.-maz }\end{array}$ & 7534 & 7188 & 7320 & 7338 & 6571 & 4815 & 3081 \\
\hline $\begin{array}{c}\text { Construction works } \\
\text { contracts awarded } \\
\text { in the province. war.-maz. }\end{array}$ & 2398 & 2063 & 1916 & 1876 & 2002 & 1530 & 1054 \\
\hline $\begin{array}{l}\text { Contracts awarded } \\
\text { the formula "Z and } \mathrm{W} \text { " } \\
\text { in the province. war.-maz. }\end{array}$ & 9 & 13 & 9 & 7 & 12 & 8 & 7 \\
\hline $\begin{array}{l}\text { Construction works } \\
\text { contracts awarded } \\
\text { in the formula „Z and W” } \\
\text { in the province. war.-maz. }\end{array}$ & 4 & 10 & 7 & 5 & 12 & 8 & 7 \\
\hline
\end{tabular}

Source: Own calculations based on Public Procurement Bulletin.

*) Not included contracts that were published in the journal of the EU.

Table 5. The number of public contracts awarded in the formula " $\mathrm{Z}$ and W" according to the construction of the structure of investment projects in the Kujawsko-Pomorskie and Warmia-Mazury in the years 2010-2016

\begin{tabular}{|c|c|c|c|}
\hline Ord. & Type of works & $\begin{array}{c}\text { Total public } \\
\text { procurement } \\
\text { in the province. } \\
\text { Kujawsko- } \\
\text { Pomorskie }\end{array}$ & $\begin{array}{c}\text { Total public } \\
\text { procurement } \\
\text { in the province. } \\
\text { Warmia-Mazury }\end{array}$ \\
\hline 1 & $\begin{array}{c}\text { Renovation, modernization, revitalization, alteration, } \\
\text { adaptation, thermo-modernization of buildings }\end{array}$ & 12 & 18 \\
\hline 2 & Construction of new facilities & 6 & 3 \\
\hline 3 & $\begin{array}{c}\text { Road infrastructure (including construction and } \\
\text { reconstruction of roads, culverts, bridges, sidewalks, } \\
\text { street lighting, investment areas) }\end{array}$ & 5 & 11 \\
\hline
\end{tabular}




\begin{tabular}{|c|c|c|c|}
\hline 4 & $\begin{array}{c}\text { Municipal infrastructure including environment } \\
\text { (including sewage treatment plants, water and sewage } \\
\text { networks., Landfill) }\end{array}$ & 2 & 4 \\
\hline 5 & $\begin{array}{c}\text { Municipal infrastructure including sport and tourism } \\
\text { (including playgrounds, sports fields, marinas, bike } \\
\text { paths) }\end{array}$ & 10 & 6 \\
\hline 6 & $\begin{array}{c}\text { Technical infrastructure (eg cranes, solar collectors, } \\
\text { pumps, fiber optic networks, masts) }\end{array}$ & 8 & 53 \\
\hline & Total & 43 & 11 \\
\hline
\end{tabular}

Source: Own study based on the Public Procurement Bulletin.

\section{Summary}

The analysis of public contracts awarded in Poland in the years 2010-2016 helped to formulate conclusions regarding tenders. In the years 2010-2016, a total of 1073481 public contracts were awarded, including 314.674 construction works contracts, which accounted for $29.31 \%$ of the total contracts awarded. The share of construction works in the total number of contracts awarded to the public tends to increase, as shown in Fig. 4.

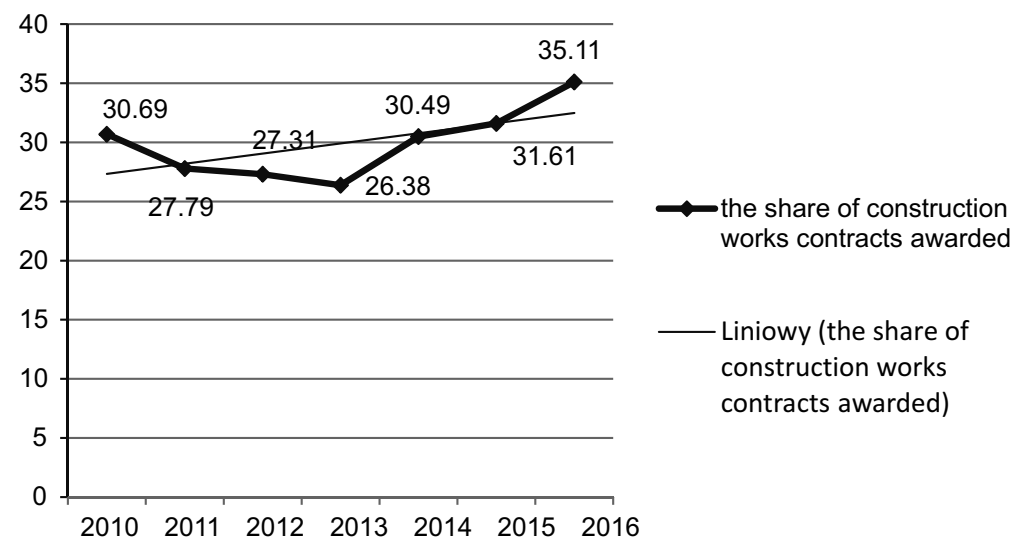

Fig. 4. Percentage of construction works in all contracts awarded in 2010-2016

The participation of formula "design and build" in the contracts awarded for construction works in the analyzed period tends to increase. In 2016, the share of formula " $\mathrm{Z}$ and W" increased more than seven times compared to the year 2010. It shows an increase in the amount purchasers willing to use this formula to award a public construction works contract.

The most common mode in the award of public construction works contracts was tender (more than $90.00 \%$ of the construction works contracts) and the free order. 


\section{References}

[1] Kowalczyk E., Modele udzielania zamówień o wartości poniżej 30000 euro, 2014, http:// www.komunikaty.pl/komunikaty/ 1,79968,16271596,Modele_udzielania_zamowien_o_wartosci_ponizej_30_000.html (access: 20.12.2016).

[2] Leśniak A., Zima K., Realizacja przedsięwzięć budowlanych w systemie zaprojektuj i wybu$d u j$, Przegląd budowlany No. 7-8, 2012, 67-70.

[3] Rozporządzenie w sprawie kwot wartości zamówień oraz konkursów, od których jest uzależniony obowiązek przekazywania ogłoszeń Urzędowi Publikacji Unii Europejskiej (Dz. U. z dnia 23 grudnia 2013 r. poz. 1735 oraz Dz. U. z dnia 28 grudnia 2015 r. poz. 2263, Dz. U. z dnia 22 sierpnia 2016 r., poz. 1386).

[4] Rozporządzeniem w sprawie zakresu informacji zawartych $\mathrm{w}$ rocznym sprawozdaniu o udzielonych zamówieniach, jego wzoru oraz sposobu przekazywania (Dz. U. z dn. 12 grudnia 2013 r., poz. 1530, Dz.U. z dn. 15 grudnia 2016 r., poz. 2038).

[5] Rozporządzenie Ministra Infrastruktury w sprawie szczegółowego zakresu i formy dokumentacji projektowej, specyfikacji technicznych wykonania i odbioru robót budowlanych oraz programu funkcjonalno-użytkowego (tj. Dz.U. z dn. 2013, poz. 1129).

[6] Tomaszewska-Pestka M., „Zaprojektuj i zbuduj”, czyli jak ominać rafy w procesie Inwestycyjnym, https://www.ergohestia.pl/korporacje/edukacja/odpowiedzialnosc-cywilna/\%E2\%80\%9Ezaprojektuj-i-zbuduj\%E2\%80\%9D--czyli-jak-ominac-rafy-w-procesie-inwestycyjnym.html\&print=1 (access: 22.04.2016).

[7] Ustawa z dnia 29 stycznia 2004 r. - Prawo zamówień publicznych (tj. z 2010 r. nr 133, poz. 759, z 2013 r., poz. 907, z 2015 r., poz. 2164 z póź. zm.).

[8] Urząd Zamówień Publicznych, Biuletyn Zamówień Publicznych, www.uzp.gov.pl (access: 10.10.2016-12.01.2017).

[9] Urząd Zamówień Publicznych, Sprawozdania Urzędu Zamówień Publicznych za lata 2010-2016 (access: 10.10.2016-12.01.2017).

[10] What is Design-Build?, [in:] „DBIA. Design-Build. Institute of America”, http://www. dbia.org/about/Pages/What-is-Design-Build.aspx (access: 12.10.2017).

[10] Zdebel-Zygmunt A., Rokicki J., System zamówień publicznych w Polsce, Warszawa, Difin, 2014. 